\title{
Egyptology
}

\section{Lana Troy}

During the period 1986-1990 a number of conferences were related to the subject of Egyptology, and covering the areas of linguistics, Nubiology, religion and computer technology. All of these conferences are represented in the publication of papers. Both popular and scientific descriptions of monuments and artefacts are found in the bibliography from these years as well as, studies related to the contact between Egypt and the Mediterranean and a new beginning grammar in Middle Egyptian.

Lana Troy, Department of Egyptology, Uppsala University, S-753 10 Uppsala, Sweden.

During the period 1986-1990 a number of conferences were either held in Uppsala or co-sponsered by the Department of Egyptology.

In May 1986 a conference on new developments in the analysis of ancient Egyptian grammar was held in Helsingör, Denmark. It was co-sponsered by the Department of Egyptology, Uppsala (Gertie Englund) and the Carsten Niebuhr Institute of Ancient Near Eastern Studies, Copenhagen University (Paul John Frandsen). It was an international group consisting of ca 30 participants. The papers were printed as Volume 1 of CNI (Publications of the Carsten Niebuhr Institute; cf. Englund \& Frandsen 1986). This conference was the first limited to the problems of Egyptian linguistics. It has been followed by another meeting in Los Angeles.

In August of the same year Uppsala was the site of the Sixth International Conference for Nubian Studies. Sponsored by Sweden's Royal Academy of Letters and Antiquities, it was attended by ca 120 scholars, with over 70 presentations being made. The conference covered the different periods of Nubian prehistory and history, from Palaeolithic to modern times. A selec- tion of the papers was published as a volume in the Conference series of the Academy, under the editorship of Tomas Hägg (1986), Professor of Classics, University of Bergen.

Ancient Egyptian religion and the use of the computer in Egyptological studies were the subjects of conferences held in 1987. In March of that year a small group of Scandinavian Egyptologists and historians of religion gathered to discuss the special character of Egyptian thought, or 'la pensée égyptienne". This was the first of four meetings later held in Bergen (1988), Copenhagen (1990) and Uppsala (1992) covering topics relating to Egyptian religion. Eleven papers from the 1987 and 1988 meetings were published as The Religion of the Ancient Egyptians. Cognitive Structures and Popular Expressions (Englund 1989a).

The Third Annual Round Table Conference, Egyptology and Informatics, was held in Uppsala in July of 1987. There were 23 participants from nine countries, including Egypt and the United States. The topics covered included the use of the computer in the production of hieroglyphic fonts, the formation of a database as the source for the new edition of the standard dictionary (Wörterbuch der aegyptischen 
Sprache, Berlin), as well as the computer's role in the application of new methods of analysis of both monumental decoration and archaeological finds (cf. below Englund ed. 1988; Sinclair \& Troy 1988).

\section{PUBLICATIONS CONCERNING THE MONUMENTS OF ANCIENT EGYPT AND NUBIA}

Two works presented ancient Egyptian monuments, in Egypt and the Sudan, to a broader public. Säve-Söderbergh (1987) compiled a thorough survey of the surviving monuments of ancient Nubia against the background of the international rescue project which began in 1959 and was concluded with the inauguration of the new site of the temple of Philae in 1980. SäveSöderbergh describes in detail the organisation of the project and the various phases in moving e.g. Abu Simbel, as well as the present location of other temples moved to sites in Nubia as well as those found today in various European and American museums.

George \& Peterson (1988) complied a Swedish language text which gives a brief introduction to some of the more important temples of the ancient Egyptian period. The major constructions of the Old and Middle Kingdom are described with a few words. The text concentrates however on the major New Kingdom (Karnak, Abydos, Abu Simbel) and Greco-Roman (Dendera, Edfu, Philae) temples. The text is illustrated with numerous black and white and a smaller number colour photographs.

\section{ARCHAEOLOGICAL PUBLICATIONS}

Volume 4 of the Scandinavian Joint Expedition to Sudanese Nubia was published in 1989 (ed. T. Säve-Söderbergh). This volume documented those sites associated with the native Middle Nubian cultures (C-Group, Pan-grave and Kerma) from the period corresponding to the First Intermediate to the early New Kingdom (ca 2100 - 1500 BC.). In addition there is identified in this complex a group whose archaeological remains reflect a combination of native and Egyptianised customs. This group is termed the "Transitional".

This volume, besides including descriptions of the sites and non-ceramic finds, also summarises the Egyptian wheelmade pottery (Holthoer 1989a) presented in Volume $5: 1$ of this series. In addition, a multivariate analysis of the find material is presented which identifies the cultural affinity of certain artefacts (Sinclair \&Troy 1989, cf. Sinclair \& Troy 1988).

\section{ARTEFACT PUBLICATIONS}

Numerous artefacts were published and analysed in various forms during the period 1986-1990.

Several objects belonging to the Ramesside "chief chiseller" Pagarer were collected, described and published together by Holthoer (1990b). Originally excavated by Anastasi, the Danish and Swedish consul to Egypt in the 1820 s, these items have been dispersed among a number of European museums. They include a pyramidion, stelae, pillar bases and offering tables, many of which appear to be parts of a single monument.

A glass pendant depicting two birds, found in a New Kingdom tomb at Fadrus in Lower Nubia was of interest, as it confirmed this date for the advanced glass workmanship which this piece represented (Troy 1990).

The majority of artefacts documented in publication during this period either belonged to the Mediterranean Museum of Stockholm or were published by a member of the staff of that museum. The largest category of items is that representing reliefs, statues and statuettes.

Two reliefs were published during this time. The most important of these was a block ("talatat") from Amarna acquired by the museum in 1983 (MME 1983:2; George 1986). The block depicts activities presumably taking place in the palace. The 
head of a Ramesside king (MM 11416; Peterson 1987c), probably Ramses II and a fragment depicting a man (MM 11417), both have Sakkara as likely provenance, coming from the large Ramesside necropolis of Memphis.

One royal statue, originally from Elephantine now part of the Aswan collection (Aswan 1086) was published by Lindblad (1988a). Originally identified by that author as depicting the early 18th dynasty king Amosis, the discovery of a fragment of the throne of the statue, inscribed Tuthmosis II, seemed to contradict that identification. Lindblad asserts that the inscription indicates a double usurpation of the statue.

The fragments of four private statues from the Middle Kingdom are also described by Lindblad (1986, 1988b). One of these (MM 11236), coming from the delta, depicts a standing male figure, said to date to the time of Sesostris II. Three fragments, all black granite (MM 11235, MM 11234, 1969:160; Lindblad 1988) one of a women, two of men, also may be dated to the Middle Kingdom.

Two fragmentary wooden statuettes, transferred from private ownership to that of the museum (EE 305,306) are dated to the period between the reigns of the 18 th dynasty kings Tuthmosis III - Amenhotep III (Lindblad 1990).

In addition to those statues and statuettes depicting individuals there are also small bronze figures serving as votives for the gods. Peterson (1986c) described a number of these figures, six of which represent the shrew mouse, some of which are shown standing on a votive coffin. The description of a coffin for a shrew mouse mummy is also presented, as are three bronzes representing ichneumons.

Funerary equipment is documented with the publication of the remains of two coffins. George (1987) describes the wood cross bar from the coffin of a child
(MM 19280). Dated to the 11 th dynasty, the coffin remains are inscribed with two spells from the Coffin Texts. Two fragments of a wooden coffin dated to the late Old Kingdom are published by Peterson (1986a; MME 1987:3; MME 1977:12). These are inscribed with the name of the Inspector of the Royal Physicians, Ni[an]kh-Khnum.

Funerary cones, stamped with the name of the owner, are listed by Peterson (1986b). These cones, numbering 20 in the museum collection, are discussed in relationship to the names which are found on them.

Richly decorated cosmetic objects are often included among the gifts to the dead. A fragment of a wooden comb decorated with a horse, part of private collection is published together with a fragment of a wooden spoon, with a scene of a woman among lotus flowers (MME 862; Peterson $1987 \mathrm{~b})$. The author relates these images to the love poetry of the New Kingdom.

And finally, a small collection of ethnographic material, formerly the property of Arthur Vivyan Cornish, and acquired by the museum in 1984, is presented by Peterson (1986d; MME 1984:34). Included among the Egyptological artefacts were amulets, seals and ushebtis.

\section{EGYPT AND THE MEDITERANIAN}

One author, Aström, contributed publications during the period 1986-1990, relating to Egypt's international connections. Trade between Egypt and Cyprus is illustrated by the Egyptian finds from Cypriote sites (Åström 1986a, 1987a, 1989a), as well as by comparing the archaeological remains of Egyptian Nile perch with the story of the journey of Wenamun (1989b).

The question of the chronology of the area using Minoan, Myceanean and Cypriote material cross-referenced with Egyptian, is treated in three articles (Åström 1986b, 1986c, 1987a). Mediterranean Bronze Age chronology was treated in depth at a 
Symposium held in Gothenburg in August 1987. A collection of papers, including treatment of Egyptian chronology, was published in the same year ( $₫$ ström 1987).

\section{ANCIENT EGYPTIAN GRAMMAR}

The study of ancient Egyptian grammar is represented by the co-editorship of the Conference papers for the Helsingör meeting described above (Englund and Frandsen 1986). In addition a new teaching grammar was produced by Englund in 1988, incorporating many of the new trends discussed at the conference.

\section{ANCIENT EGYPTIAN RELIGION AND IDEOLOGY}

The conference papers from the meetings in Uppsala (1987) and Bergen (1988, cf. Englund 1989a), included a number of contributions from Uppsala. Englund treated the conceptual structure of ancient Egyptian thought in two contributions (Englund $1989 b, 1989 c)$ and Troy looked at the use of feminine personification in the presentation of the group of the gods known as the Ennead (Troy 1989a). In addition, under the heading of "practical religion", the mythical elements of the texts known as the Calendars of Good and Bad Days were examined by Troy (1989b).

An additional conference, hosted by the department of Ancient Culture and Society in 1985 , on the topic of the religious phenomenon of offering, included two Egyptological contributions. One of these dealt with the multi-levelled process of offering (Bergman 1987), while the other covered the specifically Egyptian functions and associations of the offering ceremony (Englund 1987).

A series of popular, interdisciplinary lectures, held in Lund, is the source for a Swedish language article discussing the relationship of chaos and cosmos in Egyptian thought (Englund 1990).

There was one disputation during this period in the subject Egyptology. The dissertation of Troy (1986) dealt with the queenship of ancient Egypt as based upon a specific ideology which projected the feminine role as complementary to the masculine of the kingship (cf. also Troy 1987, 1987/88).

In addition Åström (1987b) describes the funerary custom of inverting a bowl at a grave site, including examples from Kerma in Upper Nubia.

\section{THE COPTO-BYZANTINE PERIOD}

The study of the Copto-Byzantine period is represented by one Swedish language contribution, dealing with the question of Coptic art and its relationship to Byzantine traditions (Holthoer 1989b).

\section{REFERENCES}

Åström, P. 1986a. Hala Sultan Tekke, an international harbour town in the Late Cypriote Bronze Age. Opuscula atheniensia 16. Stockholm.

- 1986b. Hala Sultan Tekke and its foreign relations. Acts of the International Symposium "Cyprus between the Orient and the Occident" 8-14 September 1985. Nicosia.

- 1986c. The Middle Minoan chronology again.
Pepragmenéna tô̂ E' diethnoûs kretologikô̂ synedriou 1 . Heraklion.

- 1986d. Italy, Asia Minor, Cyprus, Near East and Egypt. In: Mountjoy, P. A. (ed.) Mycenaean decorated pottery. Studies in Mediterranean Archaeology (SIMA) LXXIII. Göteborg.

- 1987a. The chronology of the Middle Cypriote Bronze Age. In: Åström, P. (ed.) High, Middle 
or Low? Acts of an international colloquium on absolute chronology held at the University of Gothenburg 20th-22ndAugust 1987 (SIMAPB-56). Göteborg.

- 1987b. Inverted Vases in Old World Religion. Journal of Prehistoric Religion 1. Göteborg. - 1989a. Katydhata, A Bronze Age site in Cyprus (SIMA LXXXVI). Partille.

- 1989b. Trade in the Late Cypriote Bronze Age. In: Peltenburg, E. (ed.) Early society in Cyprus. Edinburgh.

Bergman, J. 1987. Religio-Phenomenological Reflections on the Multi-level Process of Giving to the Gods. In: Linders, T. \& Nordquist, G. (eds) Gifts to the Gods. Proceedings of the Uppsala Symposium 1985. Boreas. Uppsala Studies in Ancient Mediterranean and Near Eastern Civilizations 15. Acta Universitatis Upsaliensis. Uppsala.

Englund, G. 1986. Egyptology and Informatics. Göttingen Miszellen Heft 93. Göttingen.

- 1987. Gifts to the Gods - a necessity for the preservation of cosmos and life. Theory and Praxis. In: Linders, T. \& Nordquist, G. (eds) Gifts to the gods. Proceedings of the Uppsala Symposium 1985. Boreas. Uppsala Studies in Ancient Mediterranean and Near Eastern Civilizations 15. Acta Universitatis Upsaliensis Uppsala.

- 1988a (ed.). Informatique et Egyptologie, No 5. Proceedings of the Third Round Table Conference Egyptology and Informatics, Uppsala, July 1-3 1987. Uppsala.

- 1988b. Middle Egyptian. An Introduction. Uppsala.

- 1989a (ed.) The Religion of the Ancient Egyptians. Cognitive Structures and Popular Expressions. Boreas. Uppsala Studies in Ancient Mediterranean and Near Eastern Civilizations 20. Acta Universitatis Upsaliensis. Uppsala.

- 1989b. Gods as a frame of reference on thinking and concepts of Thought in Ancient Egypt. In: G. Englund (ed.) The Religion of the Ancient Egyptians. Cognitive Structures and Popular Expressions. Boreas. Uppsala Studies in Ancient Mediterranean and Near Eastern Civilizations 20. Acta Universitatis Upsaliensis. Uppsala.

- 1989c. The Treatment of Opposites in Temple Thinking and Wisdom Literature. In: Englund, G. (ed.) The Religion of the Ancient Egyptians.
Cognitive Structures and Popular Expressions. Boreas. Uppsala Studies in Ancient Mediterranean and Near Eastern Civilizations 20. Acta Universitatis Upsaliensis. Uppsala.

- 1990. Från kaos till kosmisk ordning. (From Chaos to Cosmic Order.) Människan i samspel. En vänbok till Arno Werner: Lund.

Englund, G. \& Frandsen, P. J. (eds). 1986. Cross road: Chaos or the Beginning of a New Paradigm. Papers from the Conference on Egyptian Grammar; Helsingör. 28-30 May 1986. The Carsten Niebuhr Institute of Ancient Near Eastern Studies, CNI Publications, 1. Copenhagen.

George, B. 1986. Szene vom Leben in Amarna, Medelhavsmuseet Bulletin 21. Stockholm.

- 1987. Sargtextsprache 912 und 629: Zwei neue Stockholmer Varianten. Medelhavsmuseet Bulletin 22. Stockholm.

George, B. \& Peterson, B. 1988. Egyptens tempel. (The Temples of Egypt). Medelhavsmuseet Skrifter, 10. Arkeologiska Museet för Medelhavsländerna och Främre Orienten, Medelhavsmuseet. Stockholm.

Hägg, T. (ed.), 1986. Nubian Culture Past and Present. Main Papers Presented at the Sixth International Conference for Nubian Studies in Uppsala, 11-16 August 1986. Konferenser 17. Kungl. Vitterhets Historie och Antikvitets Akademien. Stockholm.

Holthoer, R. 1986a. Egyptologiska bekymmer. (Egyptological troubles). DIK forum, $\mathrm{Nr}: 21$. Nacka.

- 1986b. Sten Valter Wongsted in memoriam. Enchoria 14. Wiesbaden.

- 1988. Meeting between R. Lepsius and G.A. Wallin in 1845. Karl Richard Lepsius (1810-1884) Akten der Tagung seines 100. Todestag 10.-12.7.1984 in Halle. Schriften zur Geschichte und Kultur des Alten Orients 20. Berlin.

- 1989a. The Wheelmade Pottery in Middle Nubian Context. In: Säve-Söderbergh, I. (ed.) Middle Nubian Sites. Scandinavian Joint Expedition to Sudanese Nubia Vol. 4:1. Uddevalla.

- 1989b. Kopterna och deras konst, - nationellt eller provinsialbysantinskt. (The Copts and their art - national or provincial Byzantine). AUU Figura N.S. 23. Uppsala/Stockholm.

- 1990a. Hodja Nasreddin, the timeless oriental cosmopolitan. Proceedings of the 1st Inter- 
national Mulla Nasruddin Seminar. Ankara.

- 1990b. The monument of Pagarer - membra disjecta. S. Groll (ed.) Studies in Egyptology Vol. I. Jerusalem.

Lindblad, I. 1986. A Standing Male Figure from the Middle Kingdom. Medelhavsmuseet Bulletin 21. Stockholm.

- 1988a. An Unidentified Statue of Ahmose. Studien der altägyptischen kultur 15. Hamburg.

- 1988b. Three Private Statuettes from the Middle Kingdom at Stockholm. Medelhavsmuseet Bulletin 23. Stockholm.

- 1990. Two Standing Tomb-statuettes from the New Kingdom. Medelhavsmuseet Bulletin 25. Stockholm.

Peterson, B. 1986a. The Burial of an Egyptian Royal Physician. Medelhavsmuseet Bulletin 21. Stockholm.

- 1986b. A Handlist of the Funerary Cones in the Medelhavsmuseet. Medelhavsmuseet Bulletin 21. Stockholm.

- 1986c. Shrew Mouse and Ichneumon as Divinities. Medelhavsmuseet Bulletin 21. Stockholm.

- 1986d. World War I and the Formation of a Miniature Museum. Medelhavsmuseet Bulletin 21. Stockholm.

- 1987a. Med en kamera längst Nilen. Tidiga fotografer i Egypten. (With a camera along the Nile. Early photographers in Egypt.) Medelhavsmuseet. Arkeologiska Museet för Medelhavsländerna och Främre Orienten, Medelhavsmuseet, Skrifter 8. Stockholm.

- 1987b. Egyptian Symbols of Love. Medelhavsmuseet Bulletin 22. Stockholm.

- 1987c. Ramses II and his Follower. Medelhavsmuseet Bulletin 22. Stockholm.

Säve-Söderbergh, T. 1987. Temple and Tombs of Ancient Nubia. The International Rescue Campaign at Abu Simbel, Philae and Other Sites. Unesco. Paris.

- 1989 (ed.) Middle Nubian Sites. Scandinvian Joint Expedition to Sudanese Nubia, Vol.

\section{4:1-2. Uddevalla.}

Sinclair, P. J. J. \& Troy, L. 1988. Organizing Archaeological data from the Scandinavian Joint Expedition. In:Englund, G. (ed.) Informatique et Egyptologie, No5.Proceedings of the Third Round Table Conference Egyptology and Informatics, Uppsala, July 1-3 1987. Uppsala.

- 1989. A Multivariate Analysis. In: Säve-Söderbergh, T. (ed.) Middle Nubian Sites. Scandinavian Joint Expedition to Sudanese Nubia, Vol. 4:1. Uddevalla.

Troy, L. 1986. Patterns of Queenship in Ancient Egyptian Myth and History. Boreas. Uppsala Studies in Ancient Mediterranean and Near Eastern Civilizations 14. Acta Universitatis Upsaliensis. Uppsala.

- 1987/1988 Patterns of Queenship in Ancient Egyptian Myth and History. (Swedish text). Kungl. Humanistiska Vetenskaps-Samfundet i Uppsala. Årsbok 1987-1988. Annales Societatis Litterarum Humaniorum Regiae Upsaliensis. Uppsala.

- 1989a. The Ennead: The Collective as Goddess. A Commentary on Textual Personification. In: Englund, G. (ed.) The Religion of the Ancient Egyptians. Cognitive Structures and Popular Expressions. Boreas. Uppsala Studies in Ancient Mediterranean and Near Eastern Civilizations 20. Acta Universitatis Upsaliensis. Uppsala.

- 1989b. Have a Nice Day! Some Reflections on the Calendars of Good and Bad Days. In: Englund, G. (ed.) The Religion of the Ancient Egyptians. Cognitive Structures and Popular Expressions. Boreas. Uppsala. Studies in Ancient Mediterranean and Near Eastern Civilizations 20. Acta Universitatis Upsaliensis. Uppsala.

- 1990. The Dating of the Glass Bird Pendants. Material from the Scandinavian Joint Expedition to Sudanese Nubia. Göttingen Miszellen. Heft 114. Göttingen. 